\title{
Conditioned Media of Human Umbilical Cord Blood Mesenchymal Stem Cell Inhibits Ultraviolet B-induced Apoptosis in Fibroblasts
}

\author{
Dian Andriani Ratna Dewi ${ }^{1}$, Ferry Sandra ${ }^{2, *}$ \\ ${ }^{1}$ Moh Ridwan Meuraksa Hospital, Jl Raya Taman Mini I, Pinang Ranti, Makassar, Jakarta, Indonesia \\ ${ }^{2}$ Department of Biochemistry and Molecular Biology, Division of Oral Biology, Faculty of Dentistry, Universitas Trisakti, Jl. Kyai Tapa No.260, \\ Jakarta, Indonesia \\ *Corresponding author. E-mail: ferrysandra@gmail.com
}

Received date: Sep 12, 2018; Revised date: Nov 15, 2018; Accepted date: Nov 21, 2018

\section{Abstract}

B ACKGROUND: Ultraviolet (UV)B irradiated-skin cells may respond either by activating protective or apoptotic mechanisms. Several treatments has been reported to prevent apoptosis of the skin cell. To date, despite of the cell, secretome of mesenchymal stem cell (MSC) has been progressively explored for various treatment. Current research was conducted to find out the possible effect of MSC's secretome to protect normal cells from the UVB irradiation.

METHODS: For preparation of the conditioned media human umbilical cord blood mesenchymal stem cell (CM-hUCB-MSC), hUCB was collected and separated to collect mononuclear cell (MNC). MNC was cultured in MSC medium until passage 4, then checked for MSC biomarkers. Conditioned media was then produced from the cultured MSC. For induction of apoptosis, NIH3T3 cells were pretreated with/without CM-hUCB-MSC, prior to the UVB irradiation for 5-60 minutes. After 24 hours, apoptosis evaluation was conducted with Sub-G1 assay with hypotonic fluorochrome solution using flow cytometer.

RESULTS: The average of apoptotic cells irradiated with UVB for 30 minutes was $94.2 \%$. The 30 -minutes-UVB irradiation significantly induced apoptosis in NIH3T3 cells $(p=0.000)$. The averages of apoptotic cells by pretreatment of $0,5,10$ and $20 \%$ CM-hUCB-MSC prior to UVB irradiation were $94.2,46.8,31.8$ and $31.5 \%$, respectively. The pretreatment of 5, 10 and $20 \%$ CM-hUCB-MSC prior to UVB irradiation could significantly decrease the percentage of apoptosis caused by UVB $(p=0.001)$.

CONCLUSION: Taken together, CM-hUCB-MSC inhibited UVB-induced apoptosis in NIH3T3 cells significantly, suggesting that CM-hUCB-MSC might be a potential anti-UVB-induced apoptosis factor. Hence, further research should be explored to disclose its specific intracellular mechanism.

KEYWORDS: UVB, stem cell, conditioned media, fibroblast, apoptosis, aging, secretome, NIH3T3 cell

Indones Biomed J. 2019; 11(1): 85-90

\section{Introduction}

As the primary source of ultraviolet (UV) radiation, sunlight has three major components including UVA, UVB and UVC. Among the three, UVB irradiation has been reported as the most damaging one, which can affect until the epidermal layer of the skin.(1) Therefore, UVB is considered as one of the major risk factors for the formation of free radicals, which can further leading to acute inflammation and nonmelanoma skin cancer.(2) UVB irradiated-skin cells may respond either by activating protective or apoptotic mechanisms.(3) UVB irradiation has been reported as a strong agent in inducing genotoxicity, leading to cell apoptosis.(3) Therefore, protecting UVB-irradiated cells from apoptosis is an important approach.(4) 
Mesenchymal stem cell (MSC), can be derived from various sources, including bone marrow (5), adipose tissue (6), Wharton jelly (7), umbilical cord blood (8), dental pulp and periodontal ligament (9). Among all stem cell types, MSC is one of the most well-researched stem cell types. MSC has been widely focused due to its unique ability in self-renew and multiple-cell-lineages differentiation.(10) Therefore, there are lots of interests for the use of MSC for the clinical therapeutic application.(11,12) To date, despite of the cell, secretome of MSC has been progressively explored for various purposes. $(8,13)$ Therefore current research was conducted to find out the possible effect of MSC's secretome to protect normal cells from the UVB irradiation.

\section{Methods}

\section{Cell Culture}

NIH3T3 cells were cultured in Dulbecco's Modified Eagle Medium (Gibco, Grand Island, NY, USA), containing 10\% fetal bovine serum (Gibco) and antibiotic-antimycotic containing $200 \mathrm{units} / \mathrm{mL}$ penicillin, $200 \mu \mathrm{g} / \mathrm{mL}$ streptomycin and $0.5 \mu \mathrm{g} / \mathrm{mL}$ amphotericin (Gibco) in a humidified, $37^{\circ} \mathrm{C}$, $5 \% \mathrm{CO}_{2}$ incubator. Upon reaching $80 \%$ confluence, cells were subcultured.

\section{Preparation of Conditioned Media of Human Umbilical} Cord Blood Mesenchymal Stem Cell (CM-hUCB-MSC) The hUCB was collected from 5 healthy volunteers underwent the normal delivery procedure at Moh. Ridwan Meuraksa Hospital in Jakarta. Briefly, after volunteer signed informed consent and delivered the baby, $50 \mathrm{~mL}$ hUCB was collected ex utero immediately from the umbilical vein in blood bag containing anticoagulant. Then, blood was immediately diluted with equal amount of phosphate buffer saline (PBS) plus 2\% fetal bovine serum (FBS), then layered on top of Lymphoprep. With centrifugation at $800 \mathrm{xg}$ for 20 minutes, mononuclear cell (MNC) layer was formed and collected. Collected MNC was cultured in Mesencult media (StemCell Technologies Inc., Vancouver, Canada) containing penicillin and streptomycin. The hUCB cells in passage 4 were collected and checked for MSC biomarkers. Upon reaching $80 \%$ confluence, media of hUCB cells in passage 5 was replaced with supplementfree media and incubated for 24 hours. Media was collected and centrifuged. The resulted supernatant was used as CM-hUCB-MSC. CM-hUCB-MSC was stored in a $-20^{\circ} \mathrm{C}$ fridge. The study protocol was approved by The Ethical Committee of Faculty of Medicine Udayana University/Sanglah Central General Hospital (No. 1979/ UN14.2.2.VII.14/LP/2018).

\section{UVB-induced Apoptosis}

NIH3T3 cells were seeded, cultured overnight, pretreated with/without CM-hUCB-MSC, prior to the UVB irradiation using UVIVUE transilluminator equipped with $6 \times 8 \mathrm{~W}$ tubes, wavelength $312 \mathrm{~nm}$ (Cat No. BXT-F26.M, UVItec, Cambridge, UK) for 5-60 minutes. After UVB irradiation, NIH3T3 cells were kept in a 5\% $\mathrm{CO}_{2}$ incubator for 24 hours.

\section{Sub-G1 Assay}

Sub-G1 assay of apoptotic cells was performed as described by Sandra, et al. $(8,14)$ Briefly, treated cells were harvested and suspended in $1 \mathrm{~mL}$ of hypotonic fluorochrome solution (50 $\mu \mathrm{g} / \mathrm{mL}$ propidium iodide in $0.1 \%$ sodium citrate plus $0.1 \%$ Triton $\mathrm{X}-100$ ). The cell suspension was placed at $4^{\circ} \mathrm{C}$ in the dark for 2 hours before the flow cytometric analysis. The propidium iodide fluorescence of individual nuclei was measured with a FACSCanto II flow cytometer (Becton Dickinson, Franklin Lakes, NJ, USA) for 10,000 events at fluorescence length (FL)-2.

\section{Statistical Analysis}

Statistical analyses were performed using IBM SPSS Statistics for Macintosh version 21 (SPSS IBM, Armonk, NY, USA). Shapiro Wilk test was used as normality test. Parametric and non-parametric tests were used accordingly. Significance was expressed as $p<0.05$.

\section{Results}

\section{UVB-induced Apoptosis in NIH3T3 Cells}

NIH3T3 cells were cultured in an optimal condition with the low percentage of apoptotic cells, the average of apoptotic cells was $4.8 \%$ (Figure 1 and 2). UVB irradiation for 5 minutes did not increase apoptosis in NIH3T3 cells, the average of apoptotic cells was $4.6 \%$. However, when the treatment was prolonged to 30 minutes, a significant increment of apoptotic cells was found ( $p=0.000$, T-test). The average of apoptotic cells irradiated with UVB for 30 minutes was $94.2 \%$. Obviously, irradiation of UVB for 60 minutes significantly caused a high percentage of apoptosis in NIH3T3 cells ( $p=0.000$, T-test), the average of apoptotic cells was $96.5 \%$. 

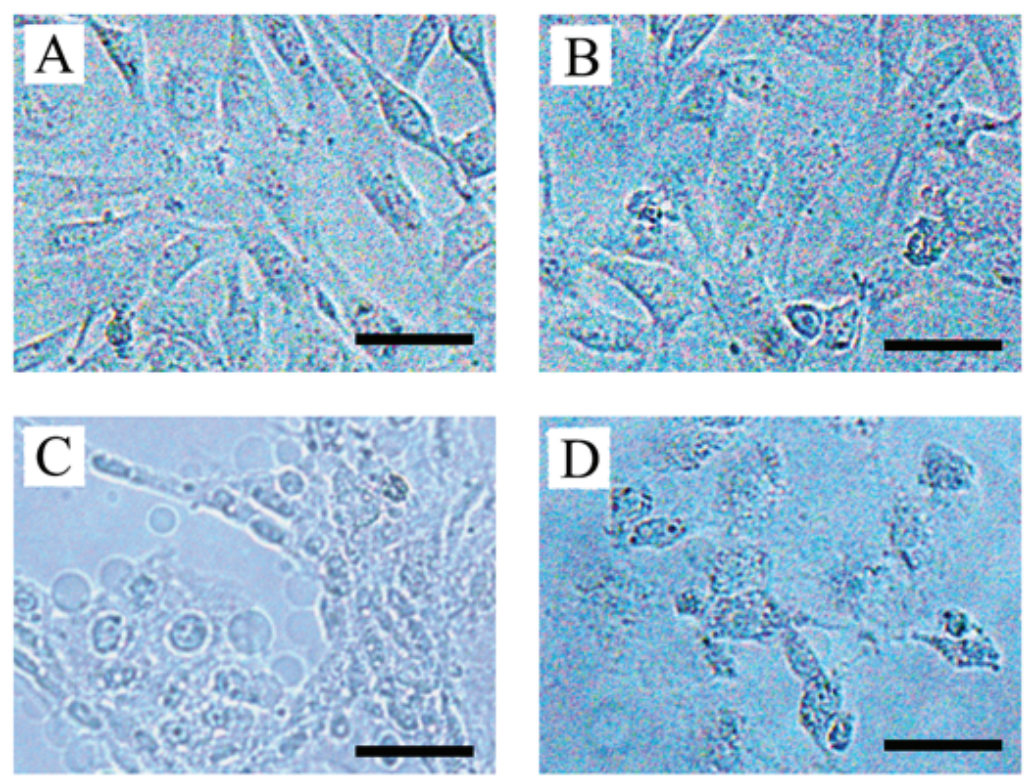

Figure 1. Morphology of UVB-irradiated NIH-3T3 cells. NIH-3T3 cells were cultured and irradiated with UVB for 0 (A), 5 (B), 30 (C) and 60 (D) minutes. Cells were documented 24 hours after the UVB irradiation, under inverted light microscope. Bar: $10 \mu \mathrm{m}$.
A

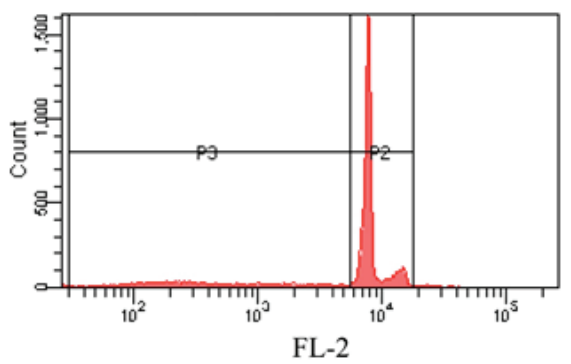

C

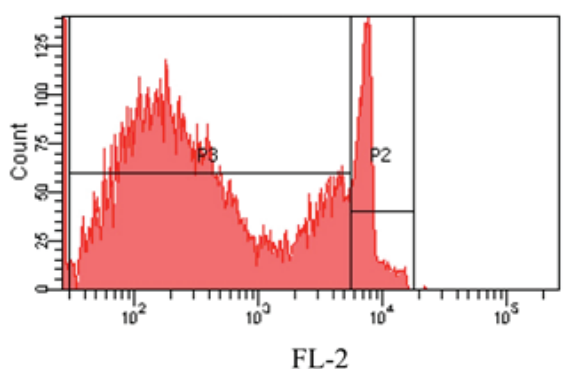

$\mathrm{E}$

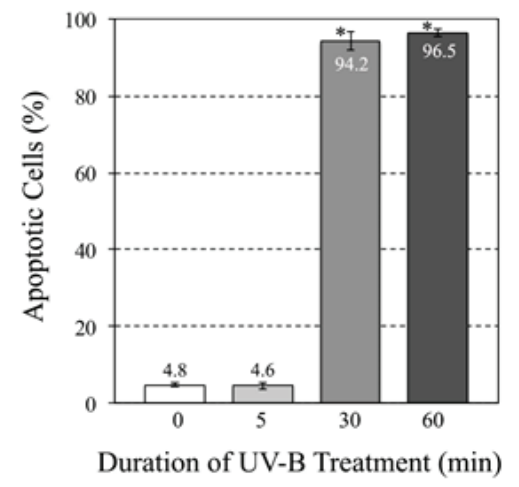

B

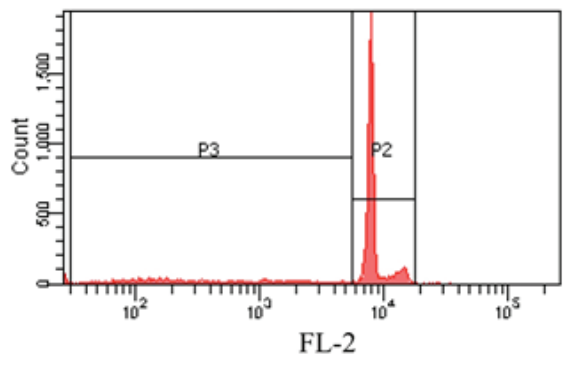

D

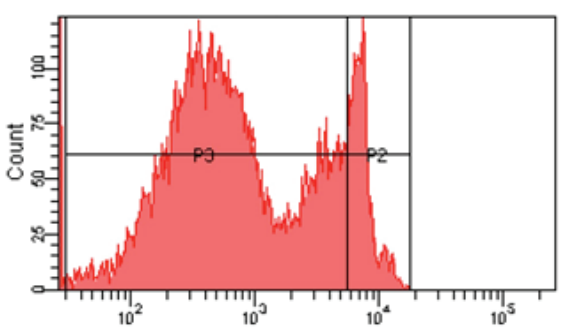

FL-2

Figure 2. UVB induced apoptosis in NIH-3T3 cells. NIH-3T3 cells were cultured and irradiated with UVB for 0 (A), 5 (B), 30 (C) and 60 (D) minutes. Cells were then subjected to Sub-G1 analysis 24 hours after the UVB irradiation. E: Percentage of apoptotic NIH-3T3 cells. P2: gating area of viable NIH-3T3 cells; P3: gating area of apoptotic NIH-3T3 cells. 


\section{CM-hUCB-MSC Inhibited UVB-induced Apoptosis in NIH3T3 Cells}

Treatment of 5, 10 and 20\% CM-hUCB-MSC did not influence apoptosis level of NIH3T3 cells. The averages of apoptotic cells were 4.5, 4.4 and $4.6 \%$, respectively. Meanwhile, the averages of apoptotic cells by pretreatment of $0,5,10$ and 20\% CM-hUCB-MSC were 94.2, 46.8, 31.8 and $31.5 \%$, respectively (Figure 3 and 4 ). The pretreatment of 5, 10 and 20\% CM-hUCB-MSC prior to UVB irradiation could significantly decrease the percentage of apoptosis caused by UVB ( $p=0.001$, Kruskal-Wallis test). The decrement of apoptosis level by CM-hUCB-MSC was in a concentration-dependent manner.

\section{Discussion}

UVB can cause apoptosis in skin cells, so that skin regeneration will be inhibited. Then the apoptotic skin cells initiate inflammatory responses leading to the manifestation of chronically exposed skin and skin aging problems.(15) Fibroblasts as one of the cells that play an important role in supporting the skin are also cells targeted by UVB to become apoptosis. $(15,16)$ The apoptosis process due to UVB irradiation can occur in a short time, within minutes. $(16,17)$ In our results, apoptosis in fibroblasts was seen in 30 minutes. This result is in accordance with previously reported results.(16) However, it should be noted that the apoptosis detected in this study was the final apoptosis stage, related to the detection method using propidium iodide. During UVB irradiation for 5 minutes, apoptosis has not been detected. However, this does not indicate that the apoptosis process has not yet begun. Based on the results of the research, it can be concluded that the apoptosis process began before 30 minutes of UVB irradiation.

There are several roles of stem cells in regeneration. Besides differentiating into target cells, stem cells are also known to have a paracrine effect, so that surrounding cells can be induced to differentiate. $(12,18)$ In addition, paracrine factors can also induce cell protection, or can even induce growth of the targeted cell.(19,20) In this study, it was proven that $\mathrm{CM}$ with a concentration of $5 \%$ could inhibit the occurrence of apoptosis caused by UVB irradiation. The optimum $\mathrm{CM}$ concentration to inhibit apoptosis caused by UVB irradiation was $10 \%$.

It has been reported that CM from adipose stem cell has an ability to protect fibroblasts from UVB.(21) In this previously reported study, conditioned media was applied after UVB irradiation, then the cell was incubated for 48 hours followed by cell viability examination.(21) Meanwhile, in the current study, CM-hUCB-MSC was applied prior to UVB irradiation, so that the CM-hUCBMSC can provide preventive cell protection against UVB irradiation. CM-hUCB-MSC could be a potential anti-UVBinduced apoptosis factor since hUCB has been reported to have a low immunogenicity.(22) In addition, hUCB which has been stored in the cord blood bank (23), could be developed for the production of CM-hUCBMSC in the future. A study in the animal model using conditioned media from adipose stem cells have also been reported.(24) The
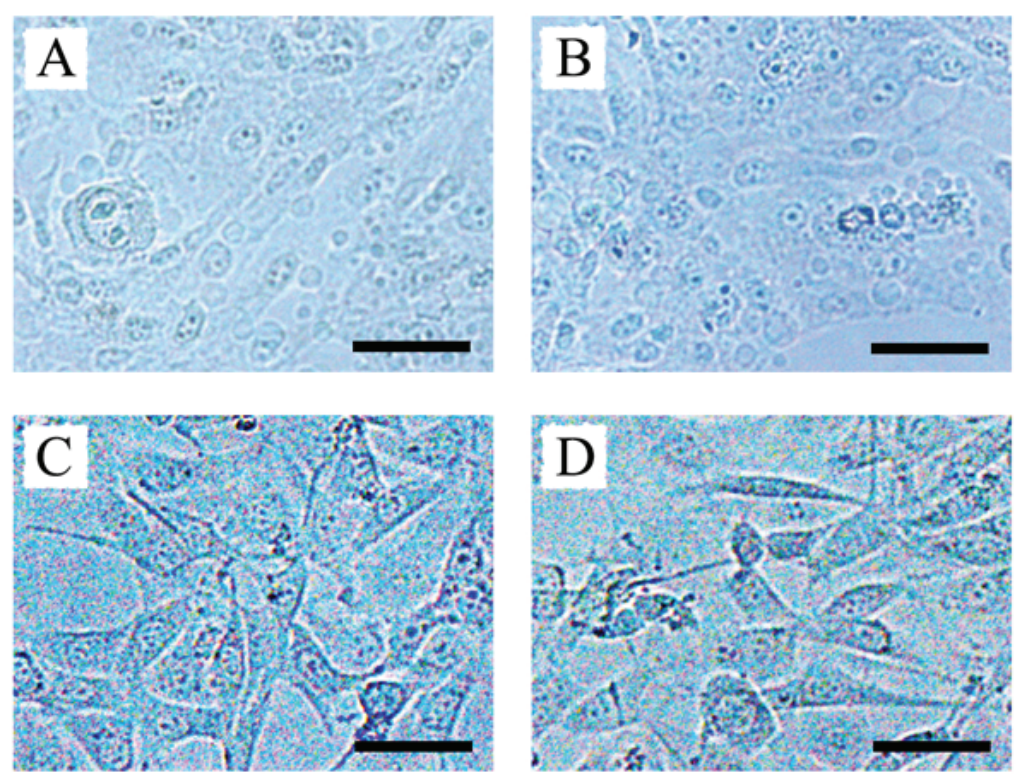

Figure 3. Morphology of CM-hUCB-MSCpretreated UVB-irradiated NIH-3T3 cells. NIH-3T3 cells were cultured, pretreated with 0 (A), 5 (B), 10 (C) and 20\% (D) CM-hUCB-MSC, and irradiated with UVB for 30 minutes. Cells were documented 24 hours after the UVB irradiation, under inverted light microscope. Bar: $10 \mu \mathrm{m}$. 
A

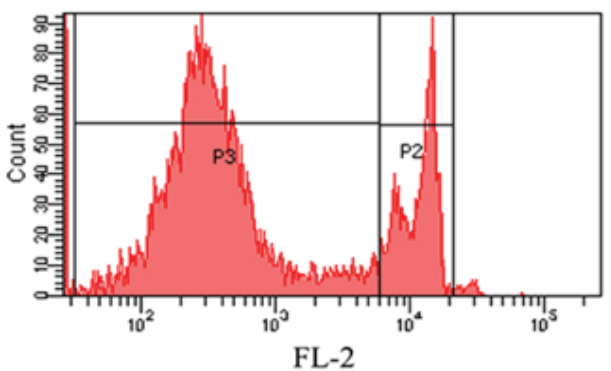

$\mathrm{C}$

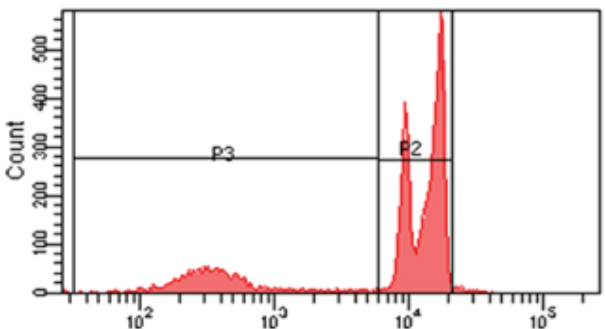

FL-2

$\mathrm{E}$

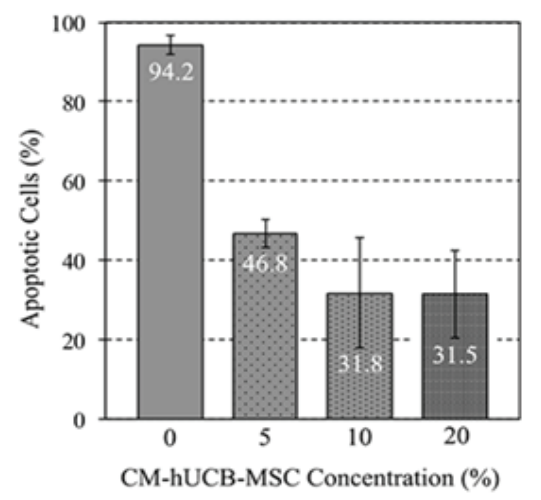

B

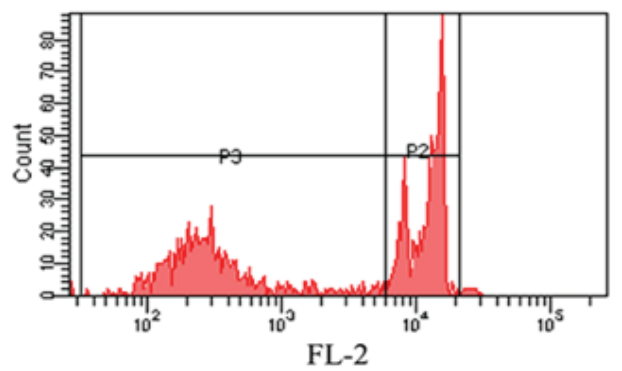

$\mathrm{D}$

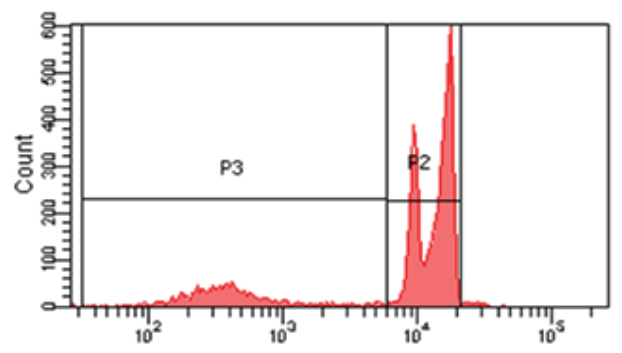

FL-2

Figure 4. CM-hUCB-MSC inhibited UVB-induced apoptosis in NIH-3T3 cells. NIH-3T3 cells were cultured, pretreated with 0 (A), 5 (B), 10 (C) and $20 \%$ (C) CM-hUCB-MSC, and irradiated with UVB for 30 minutes. Cells were then subjected to Sub-G1 analysis 24 hours after the UVB irradiation. E: Percentage of apoptotic NIH-3T3 cells. P2: gating area of viable NIH-3T3 cells; P3: gating area of apoptotic NIH-3T3 cells.

animal study concluded that CM could reduce apoptosis in human dermal fibroblasts and have an anti-wrinkle effect.24 The CM-hUCB-MSC has the potential to be tested in an experimental animal, as a continuation of this in vitro study. In parallel, a study on the CM-hUCB-MSC-induced cell protection mechanism needs to be explored as well.

\section{Conclusion}

Taken together, CM-hUCB-MSC inhibited UVB-induced apoptosis in NIH3T3 cells significantly, suggesting that CM-hUCB-MSC might be a potential anti-UVB-induced apoptosis factor. Hence, further research should be explored to disclose its specific intracellular mechanism.

\section{References}

1. Zaid MA, Afaq F, Syed DN, Dreher M, Mukhtar H. Inhibition of UVBmediated oxidative stress markers of photoaging in immortalized HaCaT keratinocyte by pomegranate polyphenol extract POMx. Photochem Photobiol. 2007; 83: 882-8.

2. Chao J, Yang YL, Yang Z, Tu Y, Cheng L, Chen B, et al. Perifosine sensitizes UVB-induced apoptosis in skin cells: new implication of skin cancer prevention? Cell Signal. 2012; 24: 1781-9.

3. Su Z, Yang Z, Xu Y, Chen Y, Yu Q. Apoptosis, autophagy, necroptosis, and cancer metastasis. Mol. Cancer. 2015; 14: 48. doi: 10.1186/ s12943-015-0321-5

4. Elmore S. Apoptosis: a review of programmed cell death. Toxicol Pathol. 2007; 35: 495-516.

5. Lubis AM, Sandhow L, Lubis VK, Noor A, Gumay F, Merlina M, et $a l$. Isolation and cultivation of mesenchymal stem cells from iliac crest bone marrow for further cartilage defect management. Acta Med Indones. 2011; 43: 178-84. 
6. Sardjono CT, Setiawan M, Frisca, Saputra V, Aniko G, Sandra F. Application of a modified method for stem cell isolation from lipoaspirates in a basic lab. Med J Indones. 2009; 18: 91-6.

7. Chouw A, Dirgantara Y, Putera BW, Sartika CR, Meutia D, Yuliana $\mathrm{P}$, et al. Proliferation and characterization of Wharton-jelly's derived mesenchymal stromal cell using plasma rich platelet and plasma platelet lysate. Cytotherapy. 2017; 19: S152. doi: 10.1016/j. jcyt.2017.02.230.

8. Sandra F, Sudiono J, Sidharta EA, Sunata EP, Sungkono DJ, Dirgantara Y, et al. Conditioned media of human umbilical cord blood mesenchymal stem cell-derived secretome induced apoptosis and inhibited growth of HeLa cells. Indones Biomed J. 2014; 6: 5762.

9. Sandra F, Sudiono J, Binartha CTO, Chouw A, Djamil MS. Growth and osteogenic differentiation of $\mathrm{CD} 117+$ dental pulp and periodontal ligament cells. Indones Biomed J. 2017; 9: 78-83.

10. Aini N, Setiawan B, Sandra F. Karakteristik biologis dan diferensiasi stem cell: fokus pada mesenchymal stem cell. CDK. 2008; 35: 64-7.

11. Sandra F, Murti H, Aini N, Sardjono C, Setiawan B. Potensi terapi sel punca dalam dunia kedokteran dan permasalahannya. JKM. 2008; 8: 94-101.

12. Halim D, Murti H, Sandra F, Boediono A, Djuwantono T, Setiawan B. Stem Cell: Dasar Teori dan Aplikasi Klinis. Jakarta: Erlangga; 2010.

13. Laksmitawati DR, Sardjono CT, Pawitan JA, Sadikin M, Sandra F. Secretion of indoleamine 2,3-dioxygenase, an immunomodulatory substance, by adipose-derived mesenchymal stem cell. Indones $\mathrm{J}$ Cancer Chemoprevent. 2010; 1: 92-8.

14. Sandra F, Sidharta MA. Caffeic acid induced apoptosis in MG63 osteosarcoma cells through activation of caspases. Mol Cell Biomed Sci. 2017; 1: 28-33.
15. McDaniel D, Farris P, Valacchi G. Atmospheric skin agingContributors and inhibitors. J Cosmet Dermatol. 2018; 17: 124-37.

16. Salucci S, Burattini S, Battistelli M, Baldassarri V, Maltarello MC, Falcieri E. Ultraviolet B (UVB) irradiation-induced apoptosis in various cell lineages in vitro. Int J Mol Sci. 2012; 14: 532-46.

17. Luchetti F, Betti M, Canonico B, Arcangeletti M, Ferri P, Galli F, et al. ERK MAPK activation mediates the antiapoptotic signaling of melatonin in UVB-stressed U937 cells. Free Radic Biol Med. 2009; 46: 339-51.

18. Sandra F, Sidiq KM, Halim D. Terapi Stem Cell - Terobosan Kedokteran Modern untuk Penderita Gagal Jantung. Jakarta: Grasindo; 2012.

19. Gnecchi M, Zhang Z, Ni A, Dzau VJ. Paracrine mechanisms in adult stem cell signaling and therapy. Circ Res. 2008; 103: 1204-19.

20. Sandra F, Lahirin R. Human umbilical cord blood serum has higher potential in inducing proliferation of fibroblast than fetal bovine serum. Mol Cell Biomed Sci. 2017; 1: 65-9.

21. Wang T, Guo S, Liu X, Xv N, Zhang S. Protective effects of adiposederived stem cells secretome on human dermal fibroblasts from ageing damages. Int J Clin Exp Pathol. 2015; 8: 15739-48.

22. Sardjono CT, Setiawan M, Suyatna FD, Japutri I, Setiawan B, Sandra F. Immunogenicity characterization of mononucleated cells originated from umbillical cord blood. Med J Indones. 2010; 19: $14-20$.

23. Wijaya MT, Sandra F. Proses dalam umbilical cord blood banking. CDK. 2007; 34: 217-20.

24. Kim WS, Park BS, Park SH, Kim HK, Sung JH. Antiwrinkle effect of adipose-derived stem cell: activation of dermal fibroblast by secretory factors. J Dermatol Sci. 2009; 53: 96-102. 